\title{
The role of credit constraints on firms' exporting and importing activities
}

\author{
David Aristei* \\ Chiara Franco ${ }^{\dagger}$
}

20th August 2014

\begin{abstract}
The paper investigates the role of credit constraints on export, import and two-way trade activities of European manufacturing firms. Using direct financial constraints indicators and accounting for endogeneity issues, we find that credit rationing significantly reduces both the probability of entering foreign markets and the intensive margins of trade. Empirical results also point out that the role of extra entry costs differs according to the location of foreign markets and to the type of imported goods and services. Conditional on trading in the EU, rationing is not an obstacle to enter additional exporting and importing markets, even though two-way traders behave differently and are negatively affected by financial constraints when they enter multiple markets.
\end{abstract}

Keywords: credit constraints, exports, imports, two-way trading

JEL Classification: C35; F10; F14; G20; G30

${ }^{*}$ Department of Economics, University of Perugia, david.aristei@unipg.it

${ }^{\dagger}$ Department of International Economics, Institutions and Development, Catholic University of Milan, chiara.franco@unicatt.it 


\section{Introduction}

The comparative advantage of a country is shaped by well functioning financial institutions, as financial frictions may prevent countries from receiving the expected benefits from international activities. The role of financing conditions on trade has been at the center of the debate long before the financial crisis started, leading to a collapse in world trade flows.

There are significant differences between the costs sustained by purely domestic firms and firms that operate also in international markets. Exporting activities involve the need to acquire information on local customers, adapt products to needs and tastes or set up new distribution networks. Another source of extra-costs relates to the degree of unpredictability of foreign sales and the difficulty of enforcing international transaction contracts, which can also affect importers (Altomonte and Békés, 2010). In the same way, importers face fixed costs of exploring new foreign markets and establishing linkages with suppliers and costs to adapt foreign intermediates and technologies to their production process.

Much of the empirical literature on financial constraints and trade has focused on exports and, following the pioneering work of Greenaway et al. (2007), mainly consisted in single country studies on the effects of credit constraints on the extensive and intensive margins of export (Mû̂ls, 2008; Minetti and Zhu, 2011; Secchi et al., 2011; Wagner, 2014b). ${ }^{1}$ Conversely, only three studies have analysed the relationship between financial constraints and import activities. Bas and Berthou (2012) develop a theoretical framework to describe the main mechanisms through which credit access affects firms' import choices and, based on Indian data, finds that firms that are ex-ante more liquid and less leveraged are more likely to import foreign capital goods. Muûls (2012) find that credit constraints matter for the extensive and intensive trade margins of Belgian firms. Exports and imports are found to be differently affected by financial factors, stressing the necessity of a comparison between the two trading activities. Wagner (2014c), using data on German firms over the years 2008-2010, shows that a better credit rating score positively influence the probability of import, the number of goods imported as well the number of countries from which goods are imported, while the share of imports on total sales is found not to be related to credit constraints.

It is worth remarking that the category of two-way traders is never taken into consideration in the literature. However, financing constraints can be relevant also for two-way traders, despite they have been shown to have the highest productivity levels Andersson et al., 2008). Two-way trading implies extra costs related to the joint entry into exporting and importing markets, which requires higher financial resources and sufficient liquidity. Nevertheless, the presence of some extra costs that are common to exporting and importing activities may reduce the additional financial resources necessary to carry out both activities (Aristei et al. 2013).

The aim of this paper is to analyse whether credit constrains affect firm's international choices, not only with respect to the export behaviour, but also contributing to the analysis of the impacts on both importing and two-way trading activities. In order to investigate our main research questions, we use data from the "European Firms in a Global Economy" (EFIGE) survey, which provides comparative data on European manufacturing firms.

As in Minetti and Zhu (2011), we test for the effect of financial constraints by using direct

\footnotetext{
${ }^{1}$ See Wagner (2014a) in this Special Issue for a comprehensive survey.
} 
binary indicators of credit rationing, based on survey responses. Our analysis offers three main contributions to the existing literature. Firstly, together with a thorough analysis of the extensive and intensive margins of export, we extend the analysis to importing firms as well as to two-way traders. Our study is thus one of the few analyses on the effects of rationing on import activities and, to the best of our knowledge, it represents the first attempt to empirically assess the impact of financing constraints on two-way trading. Secondly, we test for the presence of heterogeneities in the impacts of financial constraints on both exporting and importing activities. We use information on the geographical distribution of trade activities to assess whether the effects of rationing varies across destination and sourcing areas due to differences in extra trade costs. With respect to the importing side, we further disaggregate the effect of rationing on different types of intermediate goods and services. Thirdly, as almost all studies consist in single-country analysis, our cross country dataset allows to obtain international evidence on the effects of financial constraints on foreign trade.

Our main findings reveal that, when endogeneity of rationing is appropriately modelled, both extensive and intensive margins of export and import are negatively affected by credit constraints. Firms directly exporting from home country, those importing intermediate goods and two-way traders display the highest marginal effects. When we disentangle among different destinations and sources, we find that credit constraints are more relevant for firms that export or import in EU countries only, while entering additional markets does not significantly affect trade costs. The category of two-way traders behaves differently because the impact of financial constraints increases when firms enter multiple markets and, even though marginal effects are progressively lower when we introduce non-EU markets, credit rationing remains strongly significant.

The paper is organised as follows. Section 2 illustrates the empirical methodology, while Section 3 presents and describes the data. In Section 4 we discuss the main results obtained for extensive and intensive foreign trade margins. Section 5 offers some concluding remarks.

\section{Empirical Methods}

\subsection{Credit constraints and the extensive margin of firms' foreign trade activities}

Financially fragile firms facing credit rationing may be characterised by a lower probability of carrying out foreign trade activities as financial constraints hinder the ability of firms to face the extra costs necessary to access foreign markets. Following Minetti and Zhu (2011), the difference in operating profits when firm $i$ carries out international trade activities or not can be assumed to depend on firm's characteristics and on credit constraints:

$$
\pi_{i}^{*}=\alpha_{1}+\beta R_{i}+X_{i}^{\prime} \gamma_{1}+\epsilon_{i}
$$

where $R_{i}$ is a binary indicator equal to 1 if firm $i$ faces credit rationing, $X_{i}$ is a $k \times 1$ vector of firm control variables that may impact on firm's differential operating profits and $\epsilon_{i}$ captures unobserved heterogeneity and unknown factors affecting $\pi_{i}^{*}$. Firm $i$ will access foreign markets only if it is able to face the related extra trade costs and $\pi_{i}^{*}>0$. Assuming 
$\epsilon_{i}$ to follow a standard normal distribution $\left(\epsilon_{i} \sim N(0,1)\right)$, the probability that firm $i$ carries out any export and/or import activity can be written as:

$$
\begin{aligned}
\operatorname{prob}\left(\text { Export }_{i} / \text { Import }_{i}=1\right) & =\operatorname{prob}\left(d_{i}=1\right)=\operatorname{prob}\left(\pi_{i}^{*}>0\right) \\
& =\operatorname{prob}\left(\alpha_{1}+\beta R_{i}+X_{i}^{\prime} \gamma_{1}+\epsilon_{i}>0\right) \\
& =\Phi\left(\alpha_{1}+\beta R_{i}+X_{i}^{\prime} \gamma_{1}\right)
\end{aligned}
$$

where $d_{i}$ is an indicator of foreign trade activity and $\Phi(\cdot)$ is the standard normal CDF.

In estimating equation (2), it should be taken into account that $R_{i}$ may be endogenous with respect to the decision of entering foreign markets. The likelihood of being financially constrained reflects firm's credit risk and depends on firm characteristics and credit market conditions. Endogeneity of rationing may arise from an omitted variable issue: even after controlling for firm characteristics, some unobserved factors may affect both trade participation decision and the probability of credit rationing. As discussed in Minetti and Zhu (2011), the presence of agency problems among firm's stakeholders may increase both the probability of entering foreign markets and its exposure to rationing, leading to underestimate the negative effect of financial constraints. Correlation between foreign trade decisions and financial constraints may also reflect the impact that firm's activity abroad has on its access to the credit market. To tackle this issue, we consider a recursive bivariate probit model for the joint analysis of export/import and rationing probabilities:

$$
\left\{\begin{array}{l}
d_{i}=\mathbb{1}\left(\alpha_{1}+\beta R_{i}+X_{i}^{\prime} \gamma_{1}+\epsilon_{i}>0\right) \\
R_{i}=\mathbb{1}\left(\alpha_{2}+Z_{i}^{\prime} \lambda+X_{i}^{\prime} \gamma_{2}+\mu_{i}>0\right)
\end{array}\right.
$$

where $Z_{i}$ is a $p \times 1$ vector of variables that are assumed to affect credit rationing, but do not exert a direct effect on firm's foreign trade activities. The error terms $\epsilon_{i}$ and $\mu_{i}$ are assumed to follow a bivariate standard normal distribution:

$$
\left(\begin{array}{c}
\epsilon_{i} \\
\mu_{i}
\end{array}\right) \sim N\left[\left(\begin{array}{l}
0 \\
0
\end{array}\right),\left(\begin{array}{ll}
1 & \rho \\
\rho & 1
\end{array}\right)\right]
$$

with $\rho=\operatorname{corr}\left(\epsilon_{i}, \mu_{i}\right)$. If $\rho \neq 0, \epsilon_{i}$ and $\mu_{i}$ are correlated and univariate probit estimates of $\beta$ and $\gamma_{1}$ in (2) are inconsistent. A formal test for the exogeneity of credit constraints will then consist in testing the statistical significance of the correlation coefficient of the errors.

Despite identification of model (3) is achieved even when the same regressors appear in both equations, the inclusion of identifying instruments in the second equation makes the model robust to misspecification of error distribution and preserves the validity of exogeneity test (see Monfardini and Radice (2008)). We therefore identify the effect of rationing under the assumption that the set of instruments $Z$ is excluded from the foreign trade equation.

\subsection{Credit constraints and the intensive margin of firms' export and import activities}

We further investigate the impact of credit rationing on intensive trade margins. In the EFIGE dataset (see Section 3.1), trade intensity is measured as the share of exports/imports 
on total sales and it is characterised by a large number of observations at zero. Papke and Wooldridge (1996) showed that in these cases a fractional regression approach is appropriate to model the bounded nature of the dependent variable. Wagner (2001) has introduced fractional models in the analysis of intensive trade margins and discussed the flaws related to alternative approaches, like Tobit or two-step estimators.

In modelling fractional responses characterised by a non-negligible probability mass at zero, a crucial assumption relates on how observed zeros are interpreted. When zero observations can be interpreted as the outcome of a single decision process (i.e. a utility or profit maximising decision) a one-part fractional regression model is appropriate. Conversely, when zeros and positive values can be assumed as the result of two distinct choice mechanisms, participation and level decisions may be best modelled separately by means of two-part specifications, as in selection or zero-inflation models (see Ramalho et al. (2011) for an extended discussion). Here, we follow Wagner (2001, 2014b c) and consider a one-part model to analyse the determinants of the export/import-to-sales ratio, assuming that firms choose the profit-maximising volume of exports/imports, which might be zero or a positive quantity, and it is not necessary to separately model participation and level decisions. Formally:

$$
E\left(y_{i} \mid X_{i}, R_{i}\right)=\Phi\left(\alpha_{1}+\beta R_{i}+X_{i}^{\prime} \gamma_{1}\right)
$$

where $y_{i}$ is the share of export/import on total sales. Model (4) can be estimated by means of the robust quasi-maximum likelihood (QML) method of Papke and Wooldridge (1996).

To properly accounting for the potential endogeneity of rationing, in line with Wooldridge (2013), we consider a bivariate specification that jointly models the fractional response variable $y_{i}$ and the endogenous binary variable $R_{i}$ :

$$
\left\{\begin{array}{l}
E\left(y_{i} \mid X_{i}, R_{i}\right)=\Phi\left(\alpha_{1}+\beta R_{i}+X_{i}^{\prime} \gamma_{1}+\delta_{i}\right) \\
R_{i}=\mathbb{1}\left(\alpha_{2}+Z_{i}^{\prime} \lambda+X_{i}^{\prime} \gamma_{2}+\mu_{i}>0\right)
\end{array}\right.
$$

where $\delta_{i}$ is an omitted factor thought to be correlated with $R_{i}$ and $\delta_{i}$ and $\mu_{i}$ are assumed to be independent of $X_{i}$ and $Z_{i}$ and follow a bivariate normal distribution with correlation coefficient $\rho$ and variances equal to $\sigma_{\delta_{i}}^{2}$ and 1 , respectively. ${ }^{2}$ This approach allows us to extend the analysis of intensive trade margins of Wagner (2014b c) and Egger and Kesina (2013), by explicitly accounting for both the fractional nature of the dependent variable and the potential endogeneity of credit constraints.

\section{Data}

\subsection{Foreign Trade and Credit Rationing Indicators}

Our empirical analysis is based on the public release of the "European Firms in a Global Economy" (EFIGE) survey, coordinated by Bruegel and carried out in 2010, which provides harmonised data on a representative sample of nearly 15000 manufacturing firms (with more than 10 employees) in seven European countries: Austria, France, Germany, Hungary, Italy,

\footnotetext{
${ }^{2}$ Estimation of model (5) is equivalent to a recursive bivariate probit in which $y_{i}$ is allowed to be fractional and robust inference is used.
} 
Spain and the United Kingdom. The survey provides detailed cross-sectional information on firms' international activities, combined with data on ownership and management, workforce, R\&D and innovation activities, financing, market structure and pricing behaviour.

Questions related to foreign trade choices play a key role for the aims of our analysis. With respect to exporting activities, based on question D1 of the EFIGE questionnaire ('Has the firm sold abroad some or all of its own product/services in 2008?'), we build a binary indicator of firm direct export activity in 2008 equal to 1 if the firm either replied 'Yes, directly from home country' or 'Yes, directly from third countries where the firm produces'. The questionnaire also provides information on the intensity of exports in terms of the exportto-sales ratio (based on question D4: 'Which percentage of your 2008 annual turnover did the export activities represent?') and a breakdown of export destinations areas for both extensive and intensive margins.

Firm's importing status is defined by a dummy variable equal to 1 if the firm replied 'Yes', from abroad' to question D23 ('In 2008 has the firm purchased any services for its domestic production?') or to question D30 ('In 2008 has the firm purchased raw material or any intermediate goods for its domestic production?'), while the intensity of imports is again measured as a percentage of annual turnover. Further questions allow to distinguish the extensive margin of import by both source country and type of goods (raw materials; standardised intermediates; customised intermediates) and services (transport; communications and IT; financial services; R\&D and engineering; other services), while no disaggregated information on the import-to-sales ratio is provided.

Based on information on exports and imports, we are able to identify two-way traders and analyse the extensive margins of foreign trade for firms engaging in both trade activities. In particular, a novel contribution of our analysis is that, differently from Muûls (2012) who analyses export and import choices separately and does not distinguish between one- or two-way traders, we explicitly investigate the role of credit constraints for firms that jointly participate to both foreign trade activities.

From Table 1 we notice several heterogeneities in international trade choices. Italy and France have the highest proportions of exporting and importing firms, respectively, while Austria and the UK stand out with the highest percentage of two-way traders (38.13\% and $36.07 \%$, respectively). At the same time, Austria, Hungary and Italy have the highest conditional and unconditional export-to-sales ratios, while, focusing on importing firms, France, Hungary and Italy show the highest import-to-sales ratios.

The second group of core variables refers to measures of credit rationing. Empirical analyses have mainly relied on indirect measures of financial constraints inferred from firms' financial statements. Farre-Mensa and Ljungqvist (2013) have recently shown that commonly used indicators based on balance-sheet data do not properly identify firms that are actually constrained and may reflect differences in other firm characteristics and behaviours. Direct measures of credit constraints, despite they may be affected by possible misperceptions, allow to avoid interpretation problems of indirect indicators and have been increasingly used to assess the effect of rationing on firms' growth (Angelini and Generale, 2008), innovation and R\&D investment (Savignac, 2008) and international activities (Caggese and Cuñat, 2013). ${ }^{3}$

\footnotetext{
${ }^{3}$ Alternatively, credit scores provided by external rating agencies have been recently adopted in empirical analyses on the links between credit constraints and foreign trade activities (Secchi et al., 2011, Muûls, 2012.
} 
Table 1: Firms' average extensive and intensive margins of international activities

\begin{tabular}{|c|c|c|c|c|c|c|c|c|}
\hline \multirow[b]{3}{*}{ Country } & \multirow[b]{3}{*}{ N. of obs. } & \multirow{2}{*}{\multicolumn{3}{|c|}{ Participation (in \%): }} & \multicolumn{4}{|c|}{ Intensity (ratio over firm's total sales): } \\
\hline & & & & & All firn & & Conditional on & rticipation \\
\hline & & Direct Export & Import & Two-way Trade & Direct Export & Import & Direct Export & Import \\
\hline Austria & 443 & 58.70 & 52.79 & 38.13 & 0.2382 & 0.0429 & 0.4133 & 0.0813 \\
\hline France & 2,973 & 47.14 & 54.45 & 34.10 & 0.1330 & 0.0671 & 0.2880 & 0.1232 \\
\hline Germany & 2,935 & 42.93 & 28.91 & 18.85 & 0.1254 & 0.0219 & 0.2983 & 0.0758 \\
\hline Hungary & 488 & 51.61 & 47.35 & 32.34 & 0.2202 & 0.0654 & 0.4375 & 0.1381 \\
\hline Italy & 3,021 & 64.36 & 34.91 & 28.95 & 0.2210 & 0.0376 & 0.3451 & 0.1077 \\
\hline Spain & 2,832 & 48.55 & 39.80 & 28.07 & 0.1235 & 0.0311 & 0.2560 & 0.0781 \\
\hline UK & 2,067 & 57.31 & 49.41 & 36.07 & 0.1671 & 0.0255 & 0.2938 & 0.0515 \\
\hline Total & 14,759 & 52.01 & 41.56 & 29.19 & 0.1585 & 0.0385 & 0.3083 & 0.0927 \\
\hline
\end{tabular}

In our analysis, we consider direct indicators of financial constraints, based on firms' responses to the following questions: (i) 'During the last year, was the firm willing to increase its borrowing at the same interest' (F13) and (ii) 'During the last year, did the firm apply for more credit?' (F14). Our first measure, which we refer to as Strong rationing, treats as rationed those firms that have replied 'Yes' to the first question and 'Yes, applied for it but was not successful' to the latter. As in Minetti and Zhu (2011), we also consider a second broader measure of credit constraints (Weak rationing) and identify as weakly rationed those firms willing to increase their borrowing at the same interest rate, but they either replied ' $N o$, did not apply for it' to the second question or obtained more credit but at a higher cost (i.e., they replied 'Yes' to question F18: 'With reference to the last year has your firm experienced an increase of the cost of debt charged?'). This variable allows us to exactly identify firms that are either discouraged from applying for new credit or obtained credit at a higher rate, thus reducing the size of the loans they can afford. These alternative measures capture different intensities of financial constraints, with the strong rationing indicator expected to have a larger impact on international trade behaviour.

Figure 1 presents the distribution of strongly and weakly rationed firms. In the whole sample, $4 \%$ of the firms are strongly rationed, while $9.7 \%$ have obtained credit at higher rates or have been discouraged from applying (panel a)). When we disaggregate the analysis by country, we note significant heterogeneities: Spain and Italy display the highest unconditional frequencies of strongly ( $8.5 \%$ and $7.6 \%$, respectively) and weakly $(15.2 \%$ and $12.2 \%$, respectively) financially constrained firms. The UK is characterised by a negligible proportion of strongly rationed firms $(0.5 \%)$, while the percentage of weakly rationed firms $(9.9 \%)$ is slightly higher than the average value in the whole sample.

Analysing conditional frequencies (panel $b$ )), Italy emerges as the country with the highest rate of firms being denied credit (38.7\%), similarly to Hungary $(37.2 \%)$ and Spain (30.9\%), confirming the significant tightening in credit availability during the crisis. Comparing this evidence to that obtained from panel $a$ ), it emerges that the limited access to external financing in these countries is mainly the result of supply-side constraints rather than of low credit demand. Conversely, UK stands out as the country with the lowest condi-

Wagner, 2014b c). Scores directly reflect credit markets' evaluation on firm's creditworthiness and provide a measure of the degree of financial constraints, rather than simply classifying firms as constrained or not. 
a) All Firms

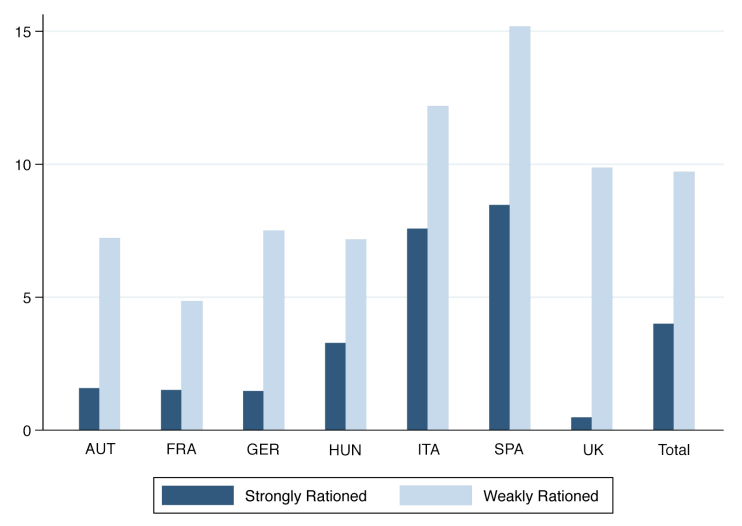

b) Conditional on apply/will to increase credit

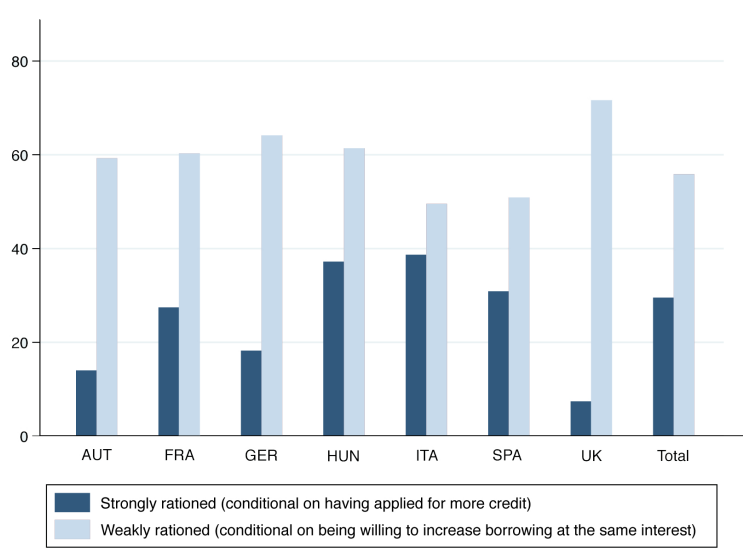

Figure 1: Distribution of strongly and weakly rationed firms

tional frequency of strongly rationed firms (7.4\%), but with the highest percentage of weakly rationed firms (71.6\%). Similar patterns emerge for Austria and Germany, suggesting that in these countries intermediaries have only partially reduced access to credit by denying applications, but tightened lending conditions (i.e., higher interest rates and tougher collateral requirements) may have increased the cost of credit and discouraged firms from applying.

Figure 2 presents the distribution of firms by credit rationing and foreign trade status. Firms engaging in international trade activities display a slightly lower probability of being strongly or weakly rationed (conditional on either applying for or willing to increase credit), but differences in observed frequencies with respect to non-internationalised firms are not statistically significant. This result may originate from the presence of several firm characteristics that simultaneously increase (or decrease) rationing probability and the likelihood of entering foreign markets. Failing in properly accounting for these common factors may generate an endogeneity bias and distort the analysis of the effects of financing constraints.

a) Export

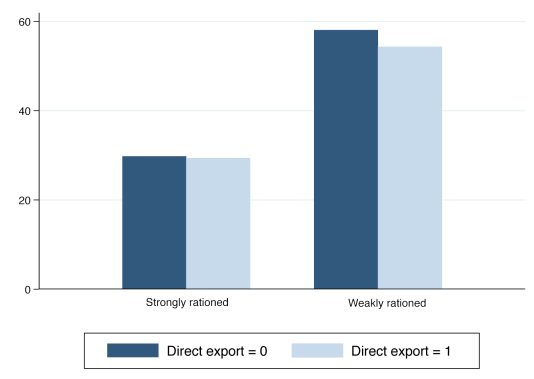

b) Import

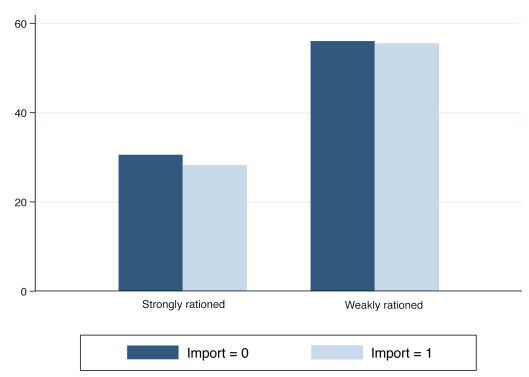

c) Two-way Trade

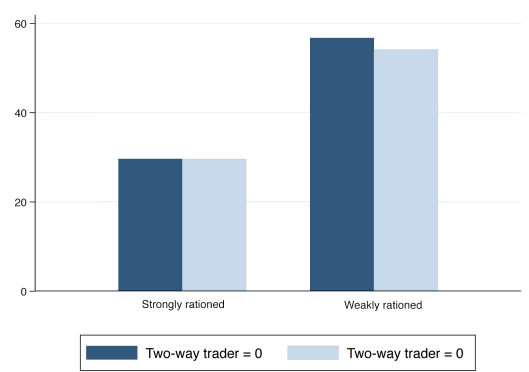

Figure 2: Foreign trade activities and credit rationing 


\subsection{Control Variables}

We control for three types of firm characteristics. Firstly, we consider variables related to the structure of the firm. We proxy firm's size using the number of employees (Employees) and its square to allow for non-linear effects, in order to assess whether larger firms have higher probabilities to export/import and control for the fact that they sustain lower costs when they need to raise funds (Wagner, 2014b). Firm's age in years (Age), included also as squared, allows to capture another important stylised fact related to the higher probability of older firms to export/import. Due to the high proportion of missing values in the measure of total factor productivity provided in the public release of the EFIGE dataset based on the estimates of Altomonte et al. (2012), and to the lack of any other balance-sheet information, we are unable to appropriately control for (partial or total) productivity at the firm level. ${ }^{4}$ We thus include the categorical measure of turnover collected through the EFIGE questionnaire that, considered together with the number of employees, allows to (partially) control for the effect of productivity on trade activities (Wagner, 2012). We then include dummies indicating the use of part-time employment or fixed-term contracts (Lab Flex) and whether the size of price margin over costs has increased (Increased Margins) as a proxy for profitability (Fryges and Wagner, 2010). We also include a dummy indicating whether the firm has a quality certification (Quality Certified), which proxies firm's efficiency, and we use the percentage of bank debt on total debt (Bank Fin) as a proxy of firm's indebtedness.

The second type of control variables accounts for firm's proprietary structure. We consider variables accounting for first shareholder's type (individual or groups of individuals) (Individual first shareh) and its nationality (Foreign first shareh) and for group membership (Group). We then control for the fact that the Chief Executive Officer (CEO) is the individual who owns the firm or a member of the controlling family (Fam CEO) and for the fact that the $\mathrm{CEO} /$ owner takes most of the decisions in every area (Centralised decisions).

A third set of controls refers to firm's technological structure of the firm and includes variables accounting for the skill composition of the workforce (High skill empl), for the share of R\&D employees ( $R \mathscr{E} \mathrm{D} \mathrm{empl}$ ), for R\&D investment ( $R \mathscr{E} D$ inv share) and process and product innovation activities (Innovation) over the last three years.

Finally, even though all models include a set of country and sector dummies, we account for differences in the industrial context and in local development by including a variable measuring average total factor productivity (Mean TFP) at the sectoral and regional level ${ }^{5}$, based on the TFP measure provided in the EFIGE dataset. As discussed above, despite the use of this productivity measure as firm-level control would severely reduce sample size, as it is computable only for around $50 \%$ of the firms in the dataset, it still allows to compute representative average productivity levels (see Altomonte and Aquilante (2012)).

Table A1 in the Appendix presents complete variable definitions and descriptive statistics.

\footnotetext{
${ }^{4}$ Information on the identity of individual firms, which would have allowed to link EFIGE data with firmlevel balance-sheet data from the Bureau van Dijk Amadeus database, is not made available by Bruegel.

${ }^{5}$ Additional information on the non-randomised classification by industry (NACE Rev.2 two-digit level) and region (NUTS1 or NUTS2 levels, depending on the country) has been provided by Bruegel.
} 


\subsection{Instrumental Variables}

Identification of the effect of rationing on both extensive and intensive margins of foreign trade is based on the assumption that the set of instrumental variables $Z$ is included only in the rationing equation. In particular, we use two indicators derived from the EFIGE survey and related to firms' debt concentration and collateral requirements, which are assumed to directly affect firm's ability to face both fixed entry costs and increased variable trade costs.

The first identification variable we consider is the percentage of total bank debt held at the firm's main bank, which provides a measure of bank borrowing concentration. An extensive literature have discussed the role of relationship lending on credit cost and availability (Berger and Udell, 2002; Elsas, 2005). Relationship lending reduces information asymmetries and allows banks to better assess firms' creditworthiness, facilitating ex-ante screening. Farinha and Santos (2002) find that an increase in the proportion of total financing provided by the main bank rises rationing probability. We thus expect that the share of total debt held at firm's main bank significantly affects rationing probability, whereas it does not play any direct effect on extensive and intensive margins of foreign trade.

The second identification instrument is a binary variable indicating whether firms are usually asked for collateral and personal guarantees when they apply for a loan. ${ }^{6}$ The effects of collateral requirements on financing availability have been examined in several theoretical and empirical studies (Steijvers and Voordeckers, 2009). Guarantees may alleviate distortions in credit allocation due to information asymmetries in bank relationships, but the increased use of secured lending may also introduce new inefficiencies: banks may find it less expensive to require a high level of guarantees than evaluating the profitability of investment projects Manove et al. (2001). Based on these considerations, we believe that this indicator of collateral requirements (despite being potentially biased by firm's misperception) may significantly affect credit rationing especially for new and small firms, while any possible effect on foreign trade can be assumed to be mediated by financing availability.

In the empirical analysis we test for instruments validity by checking both their relevance on rationing probability and their exogeneity with respect to foreign trade activities. As a further control of the validity of our identification strategy, in Section 4.1.2 we carry out a robustness check by adding to the set of instruments regional indicators encompassing overall riskiness and dependence on external financing of each sector. Using data from the Bureau van Dijk Amadeus database, we compute earnings volatility over 2006-2008 (measured as the sector-region average standard deviation of EBITDA) for firms with more than 10 employees and match this information with our data using EFIGE sectoral and regional identifiers. The choice of this variable rests upon the assumption that differences in industry/regional-specific riskiness may affect lenders' risk taking behaviour and credit policies, thus influencing firms' financial constraints. Furthermore, we control for differences in financial dependence at the sectoral and regional level by means of two alternative indicators. The first is a "subjective measure" constructed by averaging firm's self-assessment of the external financing dependence of its industry (measured on an ordinal scale ranging from 1 ('not dependent at all')

\footnotetext{
${ }^{6}$ This variable is based on questions F16 ("Which type of information does the bank normally use/ask to assess your firms credit worthiness?') and F17 ('What kind of collateral did you provide in order to obtain credit?'). It equals 1 for those firms that reply 'Collateral' to question F16 and then 'Personal guarantees from the person who manages or owns the firm' and 'Guarantees on assets belonging to the firm' to F17.
} 
to 5 ('extremely dependent')) by region and sector. To assess whether this indicator appropriately captures sectoral financial dependence and does not simply reflect firm's perception on this industry-level feature, we also considered an "objective" measure based on average firms' debt ratio at the sector-region level (computed on Amadeus data). Several studies (see Dell'Ariccia et al. (2008)) have shown that industries with higher dependence on external financing exhibit the highest reductions in growth rates, especially during financial distress periods. Belonging to more financially vulnerable sectors thus directly affects firms' output performances and financing conditions, increasing rationing probability.

\section{Results}

\subsection{The extensive margin of foreign trade activities}

\subsubsection{Baseline models}

Complete estimation results of bivariate probit models of extensive trade margins and strong rationing are presented in Table A2, while estimates of univariate probits and bivariate models of weak rationing are reported in Tables (i) and (ii) in the Online Appendix, respectively. ${ }^{7}$

Before analysing estimation results, in the last row of each Table we report results of the Rao score test of models' goodness-of-fit (Murphy, 2007; Chiburis et al., 2012). As it can be noticed, the null hypothesis that univariate and bivariate models are correctly specified cannot be rejected at the $1 \%$ significance level for all the specifications, supporting the consistency of our estimates.

Signs and significance of the coefficients of the control variables in the foreign trade equations are all in line with expectations. Focusing on the strong rationing equations, younger firms, those with lower turnover and more dependent on bank financing have a higher probability of denial. Country fixed effects are all positive and significant, confirming the lower probability of credit rationing for firms in the UK (the reference country) with respect to all the other countries. The two instrumental variables are always positive and highly significant, proving to be good predictors of rationing probability. ${ }^{8}$ The probability of credit denial increases when firms concentrate their debt and when they are asked to pledge collateral and personal guarantees. Estimated $\rho$ coefficients are positive and significant, suggesting that the unobserved determinants of both foreign trade and rationing are positively correlated and the credit constraints indicator cannot be considered as exogenous.

The coefficients of strong rationing obtained from the bivariate probits are highly significant and negative, differently from exogenous probit estimates where they are positive but statistically insignificant. These sign changes confirm that endogeneity actually affects

\footnotetext{
${ }^{7}$ The Online Appendix is available at http://www.stat.unipg.it/daristei/ $\mathrm{ICC}_{a}$ ppendix.pdf.

${ }^{8}$ Instruments exogeneity with respect to foreign trade choices has been tested by means of the approach of Evans and Schwab (1995), including the instruments, together with the credit rationing indicator, in all the foreign trade equations and testing for their joint significance. Results for strong rationing indicate that their exclusion cannot be rejected, with $p$-values equal to $0.2086,0.1467$ and 0.3055 for export, import and two-way trading models, respectively. Instruments exogeneity has been also assessed by means of over-identification tests based on linear instrumental variable estimates of extensive margins models. The $p$-values of the tests are equal to $0.2546,0.2171$ and 0.2091 and do not reject the validity of the over-identifying restrictions. This evidence further supports the hypothesis that the instruments do not directly affect firms' trade activities.
} 
empirical results. The positive signs of the rationing indicators in the univariate probits are therefore the result of not accounting for the endogeneity bias originated by the positive correlation between unobservables. This result is in line with the findings of Minetti and Zhu (2011) and can be explained by the fact that entering foreign markets, despite allowing access to more financing sources, could also increase the probability of rationing since it makes monitoring and enforceability of credit contracts more problematic and exacerbates information asymmetries between domestic lenders and borrowers. ${ }^{9}$

In the case of weak rationing (Table (ii)), even though we obtain negative point estimates, the effects on the probability of exporting and two-way trading are reduced, while the estimated coefficient turns to be insignificant on import participation. As this variable captures a less severe form of rationing, it is plausible that it does not significantly affect firm's decision to enter foreign markets.

In order to exploit the international dimension of our database, we extend the baseline bivariate probit specifications by including a full set of interactions between rationing indicators and country dummies. The endogenous interaction terms have been instrumented by adding to the set of identifying restrictions the interactions between country dummies and the two instruments considered. Results from these extended specifications, presented in Table (iii) in the Online Appendix, highlight that interactions terms are jointly insignificant in all the models, suggesting that no significant cross-country difference characterises the relationship between rationing and extensive trade margins.

As the effect of $R_{i}$ is of primary interest,in what follows we focus only on the marginal effects of rationing to have insights on the economic impact of financial constraints on trade activities. Based on estimates of model (3) the average treatment effect (ATE) of rationing on export/import probability can be computed as:

$$
\hat{\tau}_{A T E}=N^{-1} \sum_{i=1}^{N}\left[\Phi\left(\hat{\alpha}_{1}+\hat{\beta}+X_{i}^{\prime} \hat{\gamma}_{1}\right)-\Phi\left(\hat{\alpha}_{1}+X_{i}^{\prime} \hat{\gamma}_{1}\right)\right]
$$

Estimated marginal effects of credit rationing for the baseline models are reported in Table 2. Strong rationing significantly reduces the probability of exporting, importing and carrying out two-way trading activities. As it can be noticed, we are able to disentangle the effect of rationing on direct export activities from home country and from third countries where the firm produces. We find that, in this latter case, the marginal effect is significantly lower. It implies that fixed costs are lower and firms suffer less from rationing because, for example, they can rely on infrastructure and facilities of the country from which it exports. On the importing side, coherently with the findings of Mû̂ls (2012) and Wagner (2014b), strong credit rationing significantly reduces by $28 \%$ the extensive margin of import activities. In particular, the highest marginal effect characterises imports of goods, with strong rationing reducing the probability of importing intermediates by more than $33 \%$, while financial constraints do not affect imports of services from abroad. The marginal

\footnotetext{
${ }^{9}$ To check that the sign changes in strong rationing coefficients are not caused by the bivariate probit, we consider linear probability models estimated by two-stage least squares. Results confirm that the coefficients of strong rationing remain negative, even if they reduce and become significant only at the 5 and $10 \%$ levels (as an example, the coefficient of strong rationing on export probability is -0.1945 with a standard error of 0.1130. Complete results are available upon request.
} 
Table 2: Extensive Margins: marginal effects of baseline estimates

\begin{tabular}{ccc}
\hline & Strong Rationing & Weak Rationing \\
\hline \hline & & \\
Direct Export & $-0.2910^{* * *}$ & $-0.0957^{*}$ \\
- from home country & $-0.2669^{* * *}$ & $(0.0533)$ \\
& $(0.0836)$ & $-0.0908^{*}$ \\
- from third country & $-0.0440^{* *}$ & $(0.0516)$ \\
& $(0.0221)$ & -0.0058 \\
Import & $-0.2805^{* * *}$ & $(0.0190)$ \\
& $(0.0824)$ & -0.0743 \\
- Import of goods & $-0.3324^{* * *}$ & $(0.0591)$ \\
& $(0.0673)$ & $-0.1029^{*}$ \\
- Import of services & -0.0404 & $(0.0569)$ \\
& $(0.0470)$ & 0.0182 \\
Two-way Trade & $-0.2980^{* * *}$ & $(0.0277)$ \\
& $(0.0571)$ & $-0.1022^{* *}$ \\
& & $(0.0469)$
\end{tabular}

\footnotetext{
Notes: Robust standard errors, clustered at the regional level, are reported in parentheses below the estimates.

***, ** and $*$ denote significance at 1,5 and 10 percent levels, respectively.
}

effect for two-way traders is in line with the one found for the case of direct export. This suggests that extra costs sustained by these firms do not exceed to a greater extent those sustained by one-way traders. Even though overall trade costs can be higher due to the need of establishing linkages with different types of customers or suppliers, the likely presence of cost complementarities contributes to reduce the additional financial resources necessary to carry out both activities.

Marginal effects of weak rationing are much lower that those of strong rationing in all cases. Estimated effects are significant at the $10 \%$ level for direct export and import of goods and at the $5 \%$ for two-way trading and point out a reduction in the probability of carrying out these foreign trade activities by about 10 percentage points for weakly rationed firms.

\subsubsection{Robustness analysis}

Table 3 presents results of robustness checks on the baseline estimates, Firstly, we assess the robustness of our results to the choice of the set of identifying variables and re-estimate all the specifications by including the additional instruments discussed in Section 3.3. As it can be noticed from panels a1) and a2), results obtained with both the two sets of additional instruments largely confirm the evidence obtained in the baseline specifications, supporting the robustness of our identification strategy. ${ }^{10}$

As baseline models do not include controls for TFP and capital intensity due to their high proportion of missing values, we assess whether results are robust to the inclusion of these variables. Despite the estimation sample significantly reduces, strong rationing effects remain unchanged, while the effects of weak rationing turn out to be insignificant in all the specifications (panel b)).

\footnotetext{
${ }^{10}$ The additional instruments proved to be significant in the credit rationing equation of all the bivariate probit models and non significant in explaining firms' trade behaviour.
} 
Table 3: Robustness analysis

\begin{tabular}{lll}
\hline Strong Rationing & Weak Rationing & Strong Rationing \\
\hline \hline
\end{tabular}

a) Including additional instruments

a1) EBITDA volatility at the regional-sector level and a2) EBITDA volatility at the regional-sector level and "self-assessed" sectoral financial dependence

\begin{tabular}{rccccc}
\multicolumn{2}{c}{ "self-assessed" } & \multicolumn{3}{c}{ "objective" sectoral financial dependence } \\
\hline Direct Export & $-0.2876^{* * *}$ & $-0.0975^{*}$ & Direct Export & $-0.2846^{* * *}$ & $-0.0951^{*}$ \\
& $(0.0686)$ & $(0.0538)$ & & $(0.0681)$ & $(0.0534)$ \\
Import & $-0.2855^{* * *}$ & -0.0793 & Import & $-0.2890^{* * *}$ & -0.0753 \\
& $(0.0807)$ & $(0.0595)$ & & $(0.0788)$ & $(0.0589)$ \\
Two-way Trade & $-0.2946^{* * *}$ & $-0.1036^{* *}$ & Two-way Trade & $-0.2908^{* * *}$ & $-0.1002^{* *}$ \\
& $(0.0585)$ & $(0.0474)$ & & $(0.0570)$ & $(0.0473)$
\end{tabular}

b) Controlling for TFP and capital intensity Direct Export $\quad-0.2779^{* * *} \quad-0.0650$

$(0.1052) \quad(0.1207)$

Import $\quad-0.3096 * * * \quad 0.0203$

$(0.1328)$

Two-way Trade

$$
\text { (0.0980) }
$$

(0.0958) c) Excluding bank financing control

$\begin{array}{rcc}\text { Direct Export } & -0.2508^{* * *} & -0.0140 \\ & (0.0873) & (0.0448) \\ \text { Import } & -0.2290^{* * *} & -0.0375 \\ & (0.0975) & (0.0506) \\ \text { Two-way Trade } & -0.2443^{* * *} & -0.0460 \\ & (0.0730) & (0.0429)\end{array}$

d) Controlling for significantly relying on export credit e) Controlling for turnover and workforce decrease

$\begin{array}{rccccc}\text { Direct Export } & -0.3153^{* * *} & -0.0802^{*} & \text { Direct Export } & -0.2620^{* * *} & -0.0936^{*} \\ & (0.0710) & (0.0450) & & (0.0835) & (0.0535) \\ \text { Import } & -0.2720^{* * *} & -0.0655 & \text { Import } & -0.3121^{* * *} & -0.0839 \\ & (0.0862) & (0.0601) & & (0.0682) & (0.0590) \\ \text { Two-way Trade } & -0.2982^{* * *} & -0.0929^{* *} & \text { Two-way Trade } & -0.3006^{* * *} & -0.1097^{* *} \\ & (0.0611) & (0.0458) & & (0.0525) & (0.0467)\end{array}$

f) Firms already exporting/importing before 2008

$\begin{array}{rccccc}\text { Direct Export } & -0.2830^{* * *} & -0.0879^{*} & \text { Direct Export } & -0.2533^{* * *} & -0.0728 \\ & (0.0699) & (0.0502) & & (0.0740) & (0.0540) \\ \text { Import } & -0.2747^{* * *} & -0.0476 & \text { Import } & -0.2642^{* * *} & -0.0767 \\ & (0.0738) & (0.0593) & & (0.0869) & (0.0611) \\ \text { Two-way Trade } & -0.2612^{* * *} & -0.0784^{*} & \text { Two-way Trade } & -0.2677^{* * *} & -0.0921^{* *} \\ & (0.0597) & (0.0459) & & (0.0641) & (0.0448)\end{array}$

Notes: Robust standard errors, clustered at the regional level, are reported in parentheses below the estimates. Estimates are obtained using sample weights. All regressions, except c), include the same controls used in the baseline models. In panel $a$ ), we include as additional instruments the sector-region average standard deviation of EBITDA for firms with more than 10 employees (computed on Amadeus data) and a "self-assessed" (a1)) and an "objective" measure (a2)) of sectoral financial dependence. In panels $d$ ) and $e$ ), additional dummies are included to control for relying on export credit and for turnover and workforce decrease in the last year. Sample size reduces to 7194 and 13684 observations for estimations reported in panels $b$ ) and $g$ ), respectively. $* * *, * *$ and $*$ denote significance at 1,5 and 10 percent levels, respectively. 
Baseline specifications include the share of bank debt over total debt (Bank fin) as a proxy for firms' financial conditions. However, since this may contribute to decrease the marginal effect of rationing, we re-estimate extensive margins equations by excluding the bank financing control. As it can be noticed (panel $c$ )), strong rationing results are consistent with previous estimates.

We rerun estimates including a variable measuring whether firm's international activities are mainly financed through export credit (panel $d$ )), to control for the possibility that the effects of rationing may be altered when foreign trade heavily relies on external support. Results are in line with baseline estimates, except for the fact that the marginal effect of strong rationing on export becomes higher in absolute terms than those on import and two-way trading.

Baseline models are then extended with variables measuring whether firm's turnover and/or workforce have decreased during the last year. This allows to control for the possibility that the estimated negative effects of rationing may capture the impact of sale reductions and downward adjustments in employment during the crisis. Results remain basically unchanged, suggesting that the estimated marginal effects appropriately capture the impact of credit rationing.

In panel $f$ ), we evaluate the impact of rationing on trade activities of firms that have already exported or imported before 2008. The estimated marginal effects for one-way traders remain basically unchanged, suggesting that financial constraints are relevant also for firms that are active on foreign markets for a longer time, in line with the findings of Wagner $(2014 \mathrm{~b}$ c). Results also point out that strong rationing has a lower impact $(-26.1 \%)$ on firms that started to carry out two-way trading activities before 2008.

Finally, we check whether results are affected by the country composition of the EFIGE dataset. Since Austria and Hungary are significantly underrepresented (with 443 and 488 observations, respectively), we rerun regressions excluding firms from these two countries. Estimated marginal effects of strong rationing are slightly reduced, but the main findings turn out to be not significantly affected by the country composition of the sample.

\subsubsection{Entry into multiple foreign markets and different types of imported goods and services}

We extend the analysis by going deeper into the geographical distribution and composition of foreign trade activities. Firstly, we exploit information on export destinations. In our sample, only $26.8 \%$ of the exporters enter a single foreign market, while more than $51 \%$ sell their products into more than three areas. Entering in multiple markets can help firms to diversify risks and accumulate knowledge of different types of markets, but it can involve further costs. At the same time, the knowledge gained in the first foreign market can be spread over other markets, reducing the fixed costs of entering additional export destinations. Results presented in Table 4 confirm that, even though strong credit rationing negatively affects both single and multi-destinations exporting activities, the marginal effect on the probability of entering multiple markets is equal to $-25.79 \%$ and it is lower than that for single destination exports $(-37 \%)$.

We then disaggregate export activities by destinations areas, conditional on already ex- 
Table 4: Export destinations: marginal effects of rationing

\begin{tabular}{lc}
\hline Export Destinations: & \\
\hline \hline & \\
Single Destination & $-0.3700^{* * *}$ \\
Multiple Destinations & $(0.0714)$ \\
& $-0.2579^{* *}$ \\
EU & $(0.1183)$ \\
& $-0.3346^{* * *}$ \\
Outside EU & $(0.0689)$ \\
& $-0.1879^{* *}$ \\
- Other European (Non EU) Countries & $(0.0972)$ \\
& -0.1580 \\
- China \& India & $(0.1237)$ \\
& -0.0368 \\
- Other Asian Countries & $(0.0627)$ \\
& $-0.1208^{*}$ \\
- USA \& Canada & $(0.0710)$ \\
& $-0.1292^{*}$ \\
- Latin America & $(0.0769)$ \\
& -0.0324 \\
Robust standard errors, clustered at the regional level, are reported in & \\
*** $* *$ and $*$ denote significance at 1, 5 and 10 percent levels, respectively.
\end{tabular}

porting in EU countries. In the EFIGE sample, firms seem to enter the EU market as a way to facilitate access to other foreign markets: more than the $92 \%$ of the exporting firms enter the EU market and almost $70 \%$ of them also sell their products outside the EU. For this reason, we test whether credit rationing affects firms' ability to face the extra costs of entering other non-EU markets. The estimates show that for firms that are already present in the EU exporting market rationing does not affect their exporting behaviour towards other areas except for the case of exports to the US, which are characterised by a weakly significant effect.

The EFIGE survey also allows to disentangle imports on the basis of the type of intermediate goods and services imported and with respect to sourcing countries. From Table 5 we notice that credit constraints have a lower impact on firms importing intermediate goods and services from multiple countries. Moreover, we find that firms already importing from the EU are not significantly affected by credit rationing when sourcing also from non-EU countries, except for the case of importing from China and India. These results can be due to the fact that those type of markets are characterised by different technological structure that imply more difficult relationships with suppliers. Firms may need to spend more time and knowledge to adapt those imported inputs to their production process, therefore causing, at the beginning, a likely decrease in productivity.

Results from the detailed disaggregation of imported goods and services confirm that financial constraints significantly reduce the probability of importing intermediate goods only. The main reason of this evidence is that importing components and tasks imply 
Table 5: Import sources and types of imported goods and services: marginal effects of rationing

\begin{tabular}{|c|c|c|c|}
\hline \multicolumn{2}{|l|}{ Imports of goods } & \multicolumn{2}{|l|}{ Imports of services } \\
\hline \multicolumn{2}{|l|}{ Import Sources: } & \multicolumn{2}{|l|}{ Import Sources: } \\
\hline Single Source & $\begin{array}{c}-0.2658^{* * *} \\
(0.0750)\end{array}$ & Single Source & $\begin{array}{c}-0.1395^{* * *} \\
(0.0609)\end{array}$ \\
\hline Multiple Sources & $\begin{array}{c}-0.2000 * * * \\
(0.0894)\end{array}$ & Multiple Sources & $\begin{array}{l}-0.0031 \\
(0.0253)\end{array}$ \\
\hline $\mathrm{EU}$ & $\begin{array}{c}-0.3216^{* * *} \\
(0.0642)\end{array}$ & $\mathrm{EU}$ & $\begin{array}{c}-0.0697^{*} \\
(0.0412)\end{array}$ \\
\hline Outside EU & $\begin{array}{c}-0.1888^{* * * *} \\
(0.0523)\end{array}$ & Outside EU & $\begin{array}{l}-0.0169 \\
(0.0197)\end{array}$ \\
\hline - Other European (Non EU) Countries & $\begin{array}{c}0.0090 \\
(0.1919)\end{array}$ & - Other European (Non EU) Countries & $\begin{array}{l}-0.0049 \\
(0.0112)\end{array}$ \\
\hline - China \& India & $\begin{array}{c}-0.1118^{* * *} \\
(0.0421)\end{array}$ & - China \& India & $\begin{array}{l}-0.0202 \\
(0.0164)\end{array}$ \\
\hline - Other Asian Countries & $\begin{array}{c}-0.0047 \\
(0.0398)\end{array}$ & - Other Asian Countries & $\begin{array}{l}-0.0043 \\
(0.0140)\end{array}$ \\
\hline - USA \& Canada & $\begin{array}{l}-0.0280 \\
(0.1243)\end{array}$ & - USA \& Canada & $\begin{array}{l}-0.0040 \\
(0.0115)\end{array}$ \\
\hline - Latin America & $\begin{array}{c}0.0056 \\
(0.0477)\end{array}$ & - Latin America & $\begin{array}{l}-0.0002 \\
(0.0079)\end{array}$ \\
\hline \multicolumn{2}{|l|}{ Types of goods: } & \multicolumn{2}{|l|}{ Types of services: } \\
\hline Raw materials & $\begin{array}{c}-0.3475^{* * *} \\
(0.0666)\end{array}$ & Transport & $\begin{array}{c}-0.0493^{*} \\
(0.0291)\end{array}$ \\
\hline Standardised intermediates & $\begin{array}{c}0.0098 \\
(0.0624)\end{array}$ & Communications and IT & $\begin{array}{l}-0.0027 \\
(0.0136)\end{array}$ \\
\hline \multirow[t]{3}{*}{ Customised intermediates } & $\begin{array}{c}-0.1325^{* *} \\
(0.0575)\end{array}$ & Financial services & $\begin{array}{c}0.0058 \\
(0.0143)\end{array}$ \\
\hline & & R\&D and Engineering services & $\begin{array}{c}0.0174 \\
(0.0260)\end{array}$ \\
\hline & & Other services (e.g. consultants) & $\begin{array}{c}0.0084 \\
(0.0212)\end{array}$ \\
\hline
\end{tabular}

Notes: Table reports marginal effects of Strong Rationing only. Robust standard errors, clustered at the regional level, are reported in parentheses below the estimates.

***, ${ }^{* *}$ and ${ }^{*}$ denote significance at 1,5 and 10 percent levels, respectively. 
different trade costs. As pointed out by Bas and Berthou (2012), intermediate goods are usually imported on a regular basis and therefore affect firms that are less liquid, despite the fixed costs implied by this trade activity can be significantly lower than those of importing services. When we differentiate among different types of imported goods, we find significant heterogeneities in the impacts of financial constraints. Specifically, importing raw materials is particularly difficult for credit rationed firms. This is an expected result and it is related to the extremely high dependency of European firms on imports of raw materials. As pointed out by Bridgman (2012), raw materials are traded even when trade costs are high, thus increasing the role of financing constraints on their acquisition from abroad. Our results also point out that financial constraints have no impact on imports of standardised intermediates, while they hamper purchases of customised intermediates that are exclusively manufactured for the firm. Conversely, distinguishing among different types of services yields mainly non significant results and only importing of transport services is affected by credit rationing.

By combining the answers relative to country of destination and sourcing countries, we built different categories of two-way traders. In our sample, only $12.4 \%$ of the two-way traders enter a single foreign market, while almost $41 \%$ are active in multiple markets. At the same time, $75 \%$ of firms carrying out both trading activities exclusively operate within the EU market and $40 \%$ of them contemporaneously import and export outside the EU. Analysing the estimated marginal effects (Table 6), we first note that, contrary to what happens for export and import separately, extra costs of two-way trading are higher when entering multiple markets rather than a single market, causing credit constraints to negatively affect this type of international activity. The main reason for this can be related to the fact that firms may be unable to efficiently accumulate knowledge to be exploited on both destination and sourcing markets. If destinations and sourcing market are not perfectly matching in terms of knowledge, extra trade are not totally overlapping, thus increasing the financial resources necessary to carry out both activities in multiple markets. When considering different market combinations, we find that when two-way traders exclusively operate in EU markets they suffer more from credit constraints. This is true also when different combinations are considered, but the values of marginal effects are lower. In particular, firms that contemporaneously import and export outside the EU, conditional on already trading in the EU, are negatively affected by credit constraints, but to a much lower extent than those two-way trading in the EU only. The reason is that higher knowledge of importing and exporting in EU markets can contribute to scale down overall extra costs for firms carrying out two-way trading activities, which remain nevertheless higher than those sustained by one-way traders.

\subsection{The intensive margin of export and import activities}

Complete estimates from the exogenous and endogenous fractional models of export and import intensive margins are reported in Tables (iv) and (v) in the Online Appendix. From the Tables, it is firstly possible to note that most of the control variables display the same signs and significance levels as in the extensive margin analysis.

When we explicitly account for the endogeneity of financial constraints, the coefficients of strong and weak rationing on the unconditional level of export/import are both negative and highly significant, differently from the exogenous fractional models. In all the bivariate 
Table 6: Destinations and sources for two-way traders: marginal effects of rationing

\begin{tabular}{lc}
\hline Destinations and Sources: & \\
\hline \hline & $-0.1913^{* * *}$ \\
Single Destination/Source & $(0.0274)$ \\
& $-0.2274^{* * *}$ \\
Multiple Destinations/Sources & $(0.0462)$ \\
& $-0.3039^{* * *}$ \\
Export EU - Import EU & $(0.0427)$ \\
& $-0.2172^{* * *}$ \\
Export Outside EU - Import EU & $(0.0663)$ \\
& $-0.1461^{* * *}$ \\
Import Outside EU - Export EU & $(0.0434)$ \\
& $-0.1422^{* * *}$ \\
Export Outside EU - Import Outside EU & $(0.0434)$ \\
& \\
& \\
& \\
Notes: Table reports marginal effects of Strong Rationing only. \\
Robust standard errors, clustered at the regional level, are reported in \\
parentheses below the estimates. \\
$*^{* * *}{ }^{* *}$ and $*$ denote significance at 1,5 and 10 percent levels, respectively.
\end{tabular}

models, the two identification variables considered are confirmed to positively affect the probability of rationing, while they prove to be exogenous with respect to the export/importto-sale ratio. ${ }^{11}$

As for the extensive margin, the analysis of rationing is based on the marginal effects of $R_{i}$, reported in Table 7. As shown by Wooldridge (2013), average treatment effects in fractional probit models with a dummy endogenous regressor can be computed using (6) based on estimates of model (5).

In line with Muîls (2012), we find that the intensive margins of both exporting and importing activities are negatively affected by credit rationing and they just differ with respect to the size of the marginal effects.

The unconditional intensity of direct exports significantly reduces when firm faces financial constraints, as in Minetti and Zhu (2011) and Wagner (2014b). The estimated average treatment effect of credit denial on the unconditional level of export is equal to $-9.47 \%$, while firms that are discouraged from applying for credit or are charged higher interest rates have an export-to-sales ratio $5.9 \%$ lower than non-weakly rationed firms.

Differently from Wagner (2014c), who finds that the intensity of imports of German firms is not affected by financial constraints, we find that the unconditional level of imported goods and services reduces by about $4.34 \%$ and $2 \%$ when firms are strongly and weakly rationed, respectively. Deepening the analysis by type of imports, it is possible to note that the overall

\footnotetext{
${ }^{11}$ The $p$-values of the over-identification tests in models with strong and weak rationing are equal to 0.1812 and 0.4772 and to 0.2436 and 0.4754 , respectively for the export and the import-to-sales ratio.
} 
Table 7: Intensive Margins: marginal effects of credit rationing

\begin{tabular}{lcc}
\hline & Strong Rationing & Weak Rationing \\
\hline \hline & & \\
Direct Export & $-0.0947^{* * *}$ & $-0.0590^{* * *}$ \\
& $(0.0365)$ & $(0.0219)$ \\
- Direct Export in EU & $-0.0806^{* * *}$ & $-0.0345^{* *}$ \\
& $(0.0100)$ & $(0.0157)$ \\
- Direct Export Outside EU & -0.0164 & -0.0284 \\
& $(0.0186)$ & $(0.0212)$ \\
Import & $-0.0434^{* * *}$ & $-0.0200^{* * *}$ \\
& $(0.0065)$ & $(0.0080)$ \\
- Import of goods & $-0.0430^{* * *}$ & $-0.0201^{* * *}$ \\
& $(0.0045)$ & $(0.0071)$ \\
- Import of services & -0.0007 & 0.0010 \\
& $(0.0029)$ & $(0.0062)$
\end{tabular}

Notes: Bootstrapped (500 reps.) standard errors are reported in parentheses. $* * *, * *$ and $*$ denote significance at 1,5 and 10 percent levels, respectively.

marginal effect is mainly driven by the negative and significant impact on imports of goods, whereas marginal effects of both strong and weak rationing on imports of services are very small and not significantly different from zero. ${ }^{12}$

As discussed in Section 3.1, we are able to disentangle the analysis of the intensive margins of international trade activities by export destinations, but not by import source countries. Marginal effects of financial constraints on the level of EU exports are negative and significant: strong and weak rationing reduce the share of exports on total sales by $8.06 \%$ and $3.46 \%$, respectively. When we analyse how rationing affects export intensity in non-EU markets conditional on exporting to the EU, we find that neither strong nor weak rationing plays a significant role in curbing firms' foreign sales. Adding other foreign destinations does not exacerbate credit rationing effects on export intensity. This result, together with the evidence obtained for the extensive margin, thus shows that, for firms already exporting to EU markets, financial constraints neither represent a barrier for their entry into a second foreign market nor they affect firms' export intensive margin in non-EU countries.

\footnotetext{
${ }^{12}$ The reliability of the estimated marginal effects has been assessed by means of alternative estimation approaches. Linear IV and two-limit Tobit estimates (reported in Table (vi) in the Online Appendix) confirm the negative and significant effects of rationing on intensive trade margins. Moreover, the same robustness checks discussed in Section 4.1.2 have been carried out and support the stability of estimated effects (results are available upon request).
} 


\section{Conclusions}

Participation to foreign markets requires additional financial resources and sufficient liquidity to cover extra costs involved by export and import activities. This is the reason why credit constrained firms may be excluded from international activities or experience a reduction in their intensive trade margins.

Based on data from the EFIGE survey for a sample of European manufacturing firms, we provide empirical evidence on the role of credit constraints in hampering the extensive and intensive margins of firms' international activities. We also explore heterogeneities in the effects of rationing by accounting for different destination and source countries and for different types of imported goods and services. A further novelty of our approach is that we explicitly analyse the two-way traders category, which has never been examined before.

Empirical results point out that firms directly exporting their production abroad, those importing intermediate goods and two-way traders suffer to a great extent from the impact credit constraints. When considering firms' access to different types of foreign markets, we find that, conditional on already exporting or importing to/from the UE, adding other foreign markets does not exacerbate rationing problems. On the importing side, we find that credit constraints are significant only in reducing the probability of importing intermediate goods. This reveals that importing services can be less demanding in terms of financing, irrespective of the type of service imported. An interesting result emerging from the analysis of two-way traders is that firms contemporaneously exporting and importing from multiple countries are those most negatively affected by credit constraints. This may indicate that, despite the costs of accessing foreign markets can be spread over different destinations, the extra trade costs generated by both activities are not totally overlapping and increase the impact of financing constraints.

As far as the intensive margins are concerned, we find that exporting and importing levels are negatively affected by both strong and weak rationing. This evidence suggests that credit constraints are not only relevant for the extensive margins, but also significantly reduce the volumes of exports and imports by hampering firms' ability to finance both fixed and variable costs of foreign trade.

Some relevant policy implications can be singled out from our findings. Firstly, public policy measures should be aimed at reducing fixed costs of international trade activities and supporting not only firms that want to enter foreign markets, but also those willing

to expand their presence abroad. Furthermore, specific attention should be also devoted to two-way traders, which emerge as particularly vulnerable to financial constraints. As the recent financial crisis has shown, the tightening in firms' access to external financing can represents a stumbling block especially for firms involved in both trading activities and for those that do not differentiate risks and spread entry costs across different foreign markets. 


\section{References}

Altomonte, C. and T. Aquilante (2012). The EU-EFIGE/Bruegel-Unicredit dataset. Bruegel Working paper, 2012/13.

Altomonte, C., T. Aquilante, and G. Ottaviano (2012). The triggers of competitiveness: The EFIGE crosscountry report. Blueprints, Bruegel N. 738, July.

Altomonte, C. and G. Békés (2010). Trade complexity and productivity. CeFiG Working Papers 12.

Andersson, M., H. Lööf, and S. Johansson (2008). Productivity and international trade: Firm level evidence from a small open economy. Review of World Economics 144(4), 774-801.

Angelini, P. and A. Generale (2008). On the evolution of firm size distributions. The American Economic Review 98(1), 426-438.

Aristei, D., D. Castellani, and C. Franco (2013). Firms exporting and importing activities: is there a two-way relationship? Review of World Economics 149(1), 55-84.

Bas, M. and A. Berthou (2012). The decision to import capital goods in India: Firms' financial factors matter. The World Bank Economic Review 26(3), 486-513.

Berger, A. N. and G. F. Udell (2002). Small business credit availability and relationship lending: The importance of bank organisational structure. The Economic Journal 112(477), F32-F53.

Bridgman, B. (2012). The rise of vertical specialization trade. Journal of International Economics 86(1), $133-140$.

Caggese, A. and V. Cuñat (2013). Financing constraints, firm dynamics, export decisions, and aggregate productivity. Review of Economics Dynamics 16(1), 177-193.

Chiburis, R. C., J. Das, and M. Lokshin (2012). A practical comparison of the bivariate probit and linear IV estimators. Economics Letters 117(3), 762-766.

Dell'Ariccia, G., E. Detragiache, and R. Rajan (2008). The real effect of banking crises. Journal of Financial Intermediation 17(1), 89-112.

Egger, P. and M. Kesina (2013). Financial constraints and exports: evidence from Chinese firms. CESifo Economic Studies 59(4), 676-706.

Elsas, R. (2005). Empirical determinants of relationship lending. Journal of Financial Intermediation 14(1), $32-57$.

Evans, W. N. and R. M. Schwab (1995). Finishing high school and starting college: Do catholic schools make a difference? The Quarterly Journal of Economics 110(4), 941-974.

Farinha, L. A. and J. A. Santos (2002). Switching from single to multiple bank lending relationships: Determinants and implications. Journal of Financial Intermediation 11(2), 124-151.

Farre-Mensa, J. and A. Ljungqvist (2013). Do measures of financial constraints measure financial constraints? NBER Working Paper No. 19551.

Fryges, H. and J. Wagner (2010). Exports and profitability: First evidence for German manufacturing firms. The World Economy 33(3), 399-423.

Greenaway, D., A. Guariglia, and R. Kneller (2007). Financial factors and exporting decisions. Journal of International Economics 73(2), 377-395.

Manove, M., A. J. Padilla, and M. Pagano (2001). Collateral versus project screening: A model of lazy banks. Rand Journal of Economics 32(4), 726-744.

Minetti, R. and S. C. Zhu (2011). Credit constraints and firm export: Microeconomic evidence from Italy. Journal of International Economics 83(2), 109-125.

Monfardini, C. and R. Radice (2008). Testing exogeneity in the bivariate probit model: A Monte Carlo study. Oxford Bulletin of Economics and Statistics 70(2), 271-282.

Murphy, A. (2007). Score tests of normality in bivariate probit models. Economics Letters 95 (3), 374-379.

Muûls, M. (2008). Exporters and credit constraints: A firm-level approach. National Bank of Belgium, Working Paper Research No. 139.

Muûls, M. (2012). Exporters, importers and credit constraints. CEP Discussion Paper No 1169.

Papke, L. E. and J. M. Wooldridge (1996). Econometric methods for fractional response variables with an application to 401 (k) plan participation rates. Journal of Applied Econometrics 11(6), 619-632. 
Ramalho, E. A., J. J. Ramalho, and J. M. Murteira (2011). Alternative estimating and testing empirical strategies for fractional regression models. Journal of Economic Surveys 25(1), 19-68.

Savignac, F. (2008). Impact of financial constraints on innovation: What can be learned from a direct measure? Economics of Innovation and New Technology 17(6), 553-569.

Secchi, A., F. Tamagni, and C. Tomasi (2011). Export activities under financial constraints: margins, quantities and prices. Laboratory of Economics and Management SantAnna School of Advanced Studies LEM Working Paper Series 2011/24.

Steijvers, T. and W. Voordeckers (2009). Collateral and credit rationing: a review of recent empirical studies as a guide for future research. Journal of Economic Surveys 23(5), 924-946.

Wagner, J. (2001). A note on the firm size-export relationship. Small Business Economics 17(4), 229-237.

Wagner, J. (2012). International trade and firm performance: a survey of empirical studies since 2006. Review of World Economics 148(2), 235-267.

Wagner, J. (2014a). Credit constraints and exports: A survey of empirical studies using firm level data. Industrial and Corporate Change $\mathrm{X}(\mathrm{X}), \mathrm{X}-\mathrm{X}$.

Wagner, J. (2014b). Credit constraints and exports: evidence for German manufacturing enterprises. Applied Economics 46(3), 294-302.

Wagner, J. (2014c). Credit constraints and margins of import: First evidence for German manufacturing enterprises. Technical report, CESIS Electronic Working Paper Series, No. 344.

Wooldridge, J. M. (2013). Quasi-maximum likelihood estimation and testing for nonlinear models with endogenous explanatory variables. Mimeo. 


\section{Appendix}

Table A1: Control variables: definitions and descriptive statistics

\begin{tabular}{|c|c|c|c|}
\hline Variable & Definition & Mean & Std.Dev \\
\hline Age & Years since firm's establishment & 34.126 & 30.573 \\
\hline Employees & Total number of employees & 51.229 & 80.757 \\
\hline $\mathrm{R} \& \mathrm{D}$ empl & $\begin{array}{l}\text { Equals } 1 \text { if the share of RD workers is higher than the corresponding } \\
\text { national average; } 0 \text { otherwise }\end{array}$ & 0.109 & 0.311 \\
\hline High skill empl & $\begin{array}{l}\text { Equals } 1 \text { if the share of graduate employees is higher than the corresponding } \\
\text { national average; } 0 \text { otherwise }\end{array}$ & 0.278 & 0.448 \\
\hline Lab Flex & $\begin{array}{l}\text { Equals } 1 \text { if firm uses part-time employment or fixed-term contracts; } \\
0 \text { otherwise }\end{array}$ & 0.593 & 0.491 \\
\hline Individual first shareh & $\begin{array}{l}\text { Equals } 1 \text { if the first shareholder is an individual or group of individuals; } \\
0 \text { otherwise }\end{array}$ & 0.768 & 0.422 \\
\hline Foreign first shareh & Equals 1 if the first shareholder is foreign; 0 otherwise & 0.079 & 0.270 \\
\hline Group & $\begin{array}{l}\text { Equals } 1 \text { if the firm belongs to any kind of group (national or foreign); } \\
0 \text { otherwise }\end{array}$ & 0.193 & 0.395 \\
\hline Centralised decisions & $\begin{array}{l}\text { Equals } 1 \text { if the } \mathrm{CEO} / \text { owner takes most of the decisions in every area; } \\
0 \text { otherwise }\end{array}$ & 0.698 & 0.459 \\
\hline Fam CEO & $\begin{array}{l}\text { Equals } 1 \text { if the CEO is the individual (or a member of the family) who } \\
\text { owns/controls the firm; } 0 \text { otherwise }\end{array}$ & 0.640 & 0.480 \\
\hline Innovation & Equals 1 if the firm has carried out product or process innovation; 0 otherwise & 0.642 & 0.479 \\
\hline R\&D inv share & R\&D investment as a $\%$ of total turnover & 3.452 & 7.663 \\
\hline Turnover & $\begin{array}{l}\text { Turnover classes, from } 1 \text { ('less than } 1 \text { million euro') to } 7 \text { ('more than } \\
250 \text { million euro') }\end{array}$ & 2.816 & 1.252 \\
\hline Increased Margins & $\begin{array}{l}\text { Equals } 1 \text { if the size of price margin over costs has increased } \\
\text { during the last year; } 0 \text { otherwise }\end{array}$ & 0.063 & 0.244 \\
\hline Quality Certified & Equals 1 if firm has any form of quality certification; 0 otherwise & 0.571 & 0.495 \\
\hline Bank Fin & $\%$ of short and medium-long bank debt over total debt & 15.123 & 29.442 \\
\hline Mean TFP & Average TFP at the sectoral and regional level & -0.025 & 0.204 \\
\hline
\end{tabular}

Notes: descriptive statistics are computed using sample weights. 
Table A2: Extensive margins of foreign trade and strong rationing: bivariate probit results

\begin{tabular}{|c|c|c|c|c|c|c|}
\hline \multirow{3}{*}{ Strong rationing } & \multicolumn{2}{|c|}{ (1) } & \multicolumn{2}{|l|}{$(2)$} & \multicolumn{2}{|c|}{$(3)$} \\
\hline & Strong Rationing & Direct Export & Strong Rationing & Import & Strong Rationing & Two-way Trade \\
\hline & & $\begin{array}{c}-0.8675^{* * *} \\
(0.2074)\end{array}$ & & $\begin{array}{c}-0.8332^{* * *} \\
(0.2464)\end{array}$ & & $\begin{array}{c}-1.0146^{* * *} \\
(0.1912)\end{array}$ \\
\hline Age & $\begin{array}{c}-0.0037^{* *} \\
(0.0018)\end{array}$ & $\begin{array}{c}0.0042^{* * *} \\
(0.0014)\end{array}$ & $\begin{array}{c}-0.0036^{*} \\
(0.0019)\end{array}$ & $\begin{array}{c}0.0016 \\
(0.0010)\end{array}$ & $\begin{array}{c}-0.0036^{*} \\
(0.0018)\end{array}$ & $\begin{array}{c}0.0035^{* * * *} \\
(0.0013)\end{array}$ \\
\hline $\mathrm{Age}^{2}$ & $\begin{array}{c}0.0166^{*} \\
(0.0092)\end{array}$ & $\begin{array}{c}-0.0085 \\
(0.0089)\end{array}$ & $\begin{array}{c}0.0176^{*} \\
(0.0102)\end{array}$ & $\begin{array}{c}-0.0064 \\
(0.0064)\end{array}$ & $\begin{array}{l}0.0182^{*} \\
(0.0097)\end{array}$ & $\begin{array}{l}-0.0126 \\
(0.0084)\end{array}$ \\
\hline Employees & $\begin{array}{c}0.0033^{* * *} \\
(0.0012)\end{array}$ & $\begin{array}{c}0.0015^{* *} \\
(0.0007)\end{array}$ & $\begin{array}{c}0.0033^{* * *} \\
(0.0012)\end{array}$ & $\begin{array}{c}0.0022^{* * *} \\
(0.0006)\end{array}$ & $\begin{array}{c}0.0035^{* * *} \\
(0.0012)\end{array}$ & $\begin{array}{c}0.0021^{* * *} \\
(0.0006)\end{array}$ \\
\hline Employees $^{2}$ & $\begin{array}{c}-0.0057^{* *} \\
(0.0024)\end{array}$ & $\begin{array}{c}-0.0041^{* * *} * \\
(0.0015)\end{array}$ & $\begin{array}{c}-0.0057^{* *} \\
(0.0023)\end{array}$ & $\begin{array}{c}-0.0037^{* * *} \\
(0.0012)\end{array}$ & $\begin{array}{c}-0.0063^{* * *} \\
(0.0023)\end{array}$ & $\begin{array}{c}-0.0041^{* * *} \\
(0.0012)\end{array}$ \\
\hline $\mathrm{R} \& \mathrm{D}$ empl & $\begin{array}{c}0.0770 \\
(0.0674)\end{array}$ & $\begin{array}{c}0.1076^{* * *} \\
(0.0380)\end{array}$ & $\begin{array}{c}0.0524 \\
(0.0671)\end{array}$ & $\begin{array}{c}0.0181 \\
(0.0403)\end{array}$ & $\begin{array}{c}0.0775 \\
(0.0675)\end{array}$ & $\begin{array}{c}0.0799^{* *} \\
(0.0375)\end{array}$ \\
\hline High skill empl & $\begin{array}{l}-0.0184 \\
(0.0502)\end{array}$ & $\begin{array}{c}0.2651^{* * *} \\
(0.0306)\end{array}$ & $\begin{array}{l}-0.0214 \\
(0.0492)\end{array}$ & $\begin{array}{c}0.1879^{* * *} \\
(0.0281)\end{array}$ & $\begin{array}{c}-0.0164 \\
(0.0466)\end{array}$ & $\begin{array}{c}0.2112^{* * *} * \\
(0.0273)\end{array}$ \\
\hline Lab Flex & $\begin{array}{c}0.0612 \\
(0.0424)\end{array}$ & $\begin{array}{c}0.1234^{* * * *} \\
(0.0273)\end{array}$ & $\begin{array}{c}0.0420 \\
(0.0428)\end{array}$ & $\begin{array}{c}0.1129^{* * *} \\
(0.0271)\end{array}$ & $\begin{array}{c}0.0440 \\
(0.0425)\end{array}$ & $\begin{array}{c}0.1207^{* * *} \\
(0.0276)\end{array}$ \\
\hline Individual first shareh & $\begin{array}{l}-0.0892 \\
(0.0648)\end{array}$ & $\begin{array}{c}-0.0918^{* *} \\
(0.0397)\end{array}$ & $\begin{array}{c}-0.0951 \\
(0.0624)\end{array}$ & $\begin{array}{l}-0.0496 \\
(0.0362)\end{array}$ & $\begin{array}{c}-0.1024 \\
(0.0630)\end{array}$ & $\begin{array}{c}-0.1001^{* *} \\
(0.0428)\end{array}$ \\
\hline Foreign first shareh & $\begin{array}{l}-0.1196 \\
(0.1083)\end{array}$ & $\begin{array}{c}0.4377^{* * *} \\
(0.0573)\end{array}$ & $\begin{array}{l}-0.0685 \\
(0.1178)\end{array}$ & $\begin{array}{c}0.3488^{* * *} * \\
(0.0587)\end{array}$ & $\begin{array}{l}-0.0797 \\
(0.1170)\end{array}$ & $\begin{array}{c}0.3806^{* * *} \\
(0.0578)\end{array}$ \\
\hline Group & $\begin{array}{l}-0.0398 \\
(0.0802)\end{array}$ & $\begin{array}{l}-0.0330 \\
(0.0517)\end{array}$ & $\begin{array}{c}-0.0450 \\
(0.0799)\end{array}$ & $\begin{array}{c}-0.0163 \\
(0.0394)\end{array}$ & $\begin{array}{c}-0.0344 \\
(0.0796)\end{array}$ & $\begin{array}{l}-0.0054 \\
(0.0478)\end{array}$ \\
\hline Centralised decisions & $\begin{array}{c}0.0244 \\
(0.0455)\end{array}$ & $\begin{array}{c}-0.1095^{* * *} \\
(0.0295)\end{array}$ & $\begin{array}{c}0.0214 \\
(0.0468)\end{array}$ & $\begin{array}{l}-0.0372 \\
(0.0307)\end{array}$ & $\begin{array}{c}0.0170 \\
(0.0445)\end{array}$ & $\begin{array}{c}-0.0335 \\
(0.0288)\end{array}$ \\
\hline Fam Ceo & $\begin{array}{l}-0.0509 \\
(0.0448)\end{array}$ & $\begin{array}{c}0.0517^{*} \\
(0.0270)\end{array}$ & $\begin{array}{l}-0.0394 \\
(0.0455)\end{array}$ & $\begin{array}{c}0.0882^{* * *} \\
(0.0315)\end{array}$ & $\begin{array}{l}-0.0397 \\
(0.0428)\end{array}$ & $\begin{array}{c}0.0677^{* *} * \\
(0.0302)\end{array}$ \\
\hline Innovation & $\begin{array}{l}0.0824^{*} \\
(0.0488)\end{array}$ & $\begin{array}{c}0.3153^{* * *} \\
(0.0276)\end{array}$ & $\begin{array}{c}0.0733 \\
(0.0472)\end{array}$ & $\begin{array}{c}0.3361^{* * *} \\
(0.0281)\end{array}$ & $\begin{array}{l}0.0882^{*} \\
(0.0474)\end{array}$ & $\begin{array}{c}0.3367^{* * * *} \\
(0.0306)\end{array}$ \\
\hline$R \& D$ inv share & $\begin{array}{c}0.0046 \\
(0.0037)\end{array}$ & $\begin{array}{c}0.0160^{* * *} \\
(0.0023)\end{array}$ & $\begin{array}{c}0.0043 \\
(0.0034)\end{array}$ & $\begin{array}{c}0.0059^{* * *} \\
(0.0016)\end{array}$ & $\begin{array}{c}0.0041 \\
(0.0037)\end{array}$ & $\begin{array}{c}0.0094^{* * *} \\
(0.0015)\end{array}$ \\
\hline Turnover & $\begin{array}{c}-0.0831^{* * * *} \\
(0.0311)\end{array}$ & $\begin{array}{c}0.2345^{* * *} \\
(0.0220)\end{array}$ & $\begin{array}{c}-0.0812^{* * *} \\
(0.0315)\end{array}$ & $\begin{array}{c}0.2096^{* * *} \\
(0.0177)\end{array}$ & $\begin{array}{c}-0.0895 * * * \\
(0.0306)\end{array}$ & $\begin{array}{c}0.2189^{* * *} \\
(0.0207)\end{array}$ \\
\hline Increased Margins & $\begin{array}{c}0.0572 \\
(0.1030)\end{array}$ & $\begin{array}{c}0.1606^{* * *} \\
(0.0483)\end{array}$ & $\begin{array}{c}0.0638 \\
(0.1004)\end{array}$ & $\begin{array}{c}0.1558^{* * *} \\
(0.0423)\end{array}$ & $\begin{array}{c}0.0715 \\
(0.0998)\end{array}$ & $\begin{array}{c}0.2131^{* * *} \\
(0.0466)\end{array}$ \\
\hline Quality Certified & $\begin{array}{c}0.0689 \\
(0.0474)\end{array}$ & $\begin{array}{c}0.0285 \\
(0.0306)\end{array}$ & $\begin{array}{c}0.0629 \\
(0.0469)\end{array}$ & $\begin{array}{c}0.0630^{* *} \\
(0.0248)\end{array}$ & $\begin{array}{c}0.0606 \\
(0.0455)\end{array}$ & $\begin{array}{c}0.0991^{* * * *} \\
(0.0241)\end{array}$ \\
\hline Bank Fin & $\begin{array}{c}0.0063^{* * *} * \\
(0.0006)\end{array}$ & $\begin{array}{c}0.0026^{* * *} \\
(0.0005)\end{array}$ & $\begin{array}{c}0.0064^{* * *} \\
(0.0006)\end{array}$ & $\begin{array}{c}0.0015^{* * *} * \\
(0.0005)\end{array}$ & $\begin{array}{c}0.0064^{* * *} \\
(0.0006)\end{array}$ & $\begin{array}{c}0.0023^{* * *} * \\
(0.0005)\end{array}$ \\
\hline Mean TFP & $\begin{array}{c}-0.4007^{* *} \\
(0.1855)\end{array}$ & $\begin{array}{c}0.3125^{* *} \\
(0.1521)\end{array}$ & $\begin{array}{c}-0.4269^{* *} \\
(0.1872)\end{array}$ & $\begin{array}{c}0.1624 \\
(0.1130)\end{array}$ & $\begin{array}{c}-0.4464^{* *} \\
(0.1855)\end{array}$ & $\begin{array}{c}0.1637 \\
(0.1393)\end{array}$ \\
\hline Main bank share & $\begin{array}{c}0.0066^{* * *} \\
(0.0006)\end{array}$ & & $\begin{array}{c}0.0067^{* * *} \\
(0.0006)\end{array}$ & & $\begin{array}{c}0.0066^{* * *} \\
(0.0007)\end{array}$ & \\
\hline Collateral & $\begin{array}{c}0.4317^{* *} \\
(0.1856)\end{array}$ & & $\begin{array}{c}0.4675^{* *} \\
(0.1895)\end{array}$ & & $\begin{array}{c}0.4175^{* *} \\
(0.1832)\end{array}$ & \\
\hline Austria & $\begin{array}{c}0.6662^{* * *} * \\
(0.2443)\end{array}$ & $\begin{array}{l}-0.1422 \\
(0.1028)\end{array}$ & $\begin{array}{c}0.6747^{* * *} \\
(0.2277)\end{array}$ & $\begin{array}{c}-0.0769^{*} \\
(0.0399)\end{array}$ & $\begin{array}{c}0.6406^{* * * *} \\
(0.2332)\end{array}$ & $\begin{array}{l}-0.0710 \\
(0.0938)\end{array}$ \\
\hline France & $\begin{array}{c}0.9425^{* * *} * \\
(0.1318)\end{array}$ & $\begin{array}{c}-0.2358^{* * *} \\
(0.0747)\end{array}$ & $\begin{array}{c}0.8279^{* * *} \\
(0.1166)\end{array}$ & $\begin{array}{c}0.1865^{* * *} \\
(0.0560)\end{array}$ & $\begin{array}{c}0.9319^{* * *} \\
(0.1266)\end{array}$ & $\begin{array}{l}-0.0034 \\
(0.0627)\end{array}$ \\
\hline Germany & $\begin{array}{c}0.8079^{* * *} \\
(0.1216)\end{array}$ & $\begin{array}{c}-0.5345^{* * *} \\
(0.0568)\end{array}$ & $\begin{array}{c}0.8209^{* * *} \\
(0.1151)\end{array}$ & $\begin{array}{c}-0.6683^{* * *} * \\
(0.0335)\end{array}$ & $\begin{array}{c}0.8040^{* * *} \\
(0.1178)\end{array}$ & $\begin{array}{c}-0.6461^{* * *} \\
(0.0431)\end{array}$ \\
\hline Hungary & $\begin{array}{c}0.6578^{* * *} \\
(0.1745)\end{array}$ & $\begin{array}{c}0.0857 \\
(0.0694)\end{array}$ & $\begin{array}{c}0.7493^{* * *} \\
(0.1694)\end{array}$ & $\begin{array}{c}0.1216^{* *} \\
(0.0568)\end{array}$ & $\begin{array}{c}0.6946^{* * *} \\
(0.1724)\end{array}$ & $\begin{array}{c}0.1248 \\
(0.0817)\end{array}$ \\
\hline Italy & $\begin{array}{c}1.5026^{* * *} * \\
(0.1331)\end{array}$ & $\begin{array}{c}0.2392^{* * *} \\
(0.0774)\end{array}$ & $\begin{array}{c}1.3138^{* * *} \\
(0.1143)\end{array}$ & $\begin{array}{c}-0.3795^{* * *} * \\
(0.0519)\end{array}$ & $\begin{array}{c}1.4759^{* * *} \\
(0.1321)\end{array}$ & $\begin{array}{c}-0.1514^{* * *} \\
(0.0573)\end{array}$ \\
\hline Spain & $\begin{array}{c}1.2883^{* * *} \\
(0.1228)\end{array}$ & $\begin{array}{l}-0.0921 \\
(0.0771)\end{array}$ & $\begin{array}{c}1.2858^{* * *} \\
(0.1136)\end{array}$ & $\begin{array}{c}-0.1474^{* *} \\
(0.0583)\end{array}$ & $\begin{array}{c}1.2558^{* * *} \\
(0.1230)\end{array}$ & $\begin{array}{c}-0.0733 \\
(0.0653)\end{array}$ \\
\hline Intercept & $\begin{array}{c}-3.9001^{* * *} \\
(0.2364)\end{array}$ & $\begin{array}{c}-0.6734^{* * *} \\
(0.0857)\end{array}$ & $\begin{array}{c}-3.1765^{* * *} \\
(0.1718)\end{array}$ & $\begin{array}{c}-1.1379^{* * *} \\
(0.0789)\end{array}$ & $\begin{array}{c}-3.8243^{* * * *} \\
(0.2422)\end{array}$ & $\begin{array}{c}-1.5389^{* * * *} \\
(0.0931)\end{array}$ \\
\hline$\rho$ & $\begin{array}{r}0.5181 \\
(0.12\end{array}$ & & $\begin{array}{r}0.4642^{*} \\
(0.1498\end{array}$ & & $\begin{array}{r}0.670 \\
(0.1\end{array}$ & \\
\hline $\begin{array}{l}\mathrm{N} \\
\mathrm{ll}\end{array}$ & $\begin{array}{r}1455 \\
-10685\end{array}$ & & $\begin{array}{r}14590 \\
-10715 .\end{array}$ & & $\begin{array}{r}145 \\
-960\end{array}$ & \\
\hline $\begin{array}{l}\text { Goodness-of-fit } \\
\text { score test }\end{array}$ & $\begin{array}{r}12.3 \\
{[0.19}\end{array}$ & & $\begin{array}{r}11.27 \\
{[0.2578}\end{array}$ & & $\begin{array}{r}12 \\
{[0.2}\end{array}$ & \\
\hline
\end{tabular}

Notes: Robust standard errors, clustered at the regional level, are reported in parentheses below the estimates. $p$-values of the goodness-of-fit tests are reported in square brackets. All estimates are obtained using sample weights and include (unreported) sectoral controls.

$* * *, * *$ and $*$ denote significance at 1,5 and 10 percent levels, respectively. 